\title{
PENERAPAN PERATURAN MENTERI PEKERJAAN UMUM DAN PERUMAHAN RAKYAT NOMOR 11/PRT/M/2019 TENTANG SISTEM PERJANJIAN PENDAHULUAN JUAL BELI RUMAH
}

\author{
Oleh : Khairunnisah ${ }^{1}$ dan Wesley L. Hutasoit ${ }^{2}$ \\ ${ }^{1}$ Dosen Fakultas Hukum Universitas 17 Agustus 1945 Samarinda \\ ${ }^{2}$ Dosen Fakultas Ilmu Sosial dan Ilmu Politik \\ Universitas 17 Agustus 1945 Samarinda
}

\begin{abstract}
During its development, a house sale and purchase agreement made by the parties by a notary public creates rights and obligations as well as risks for the parties later. Before the agreement is agreed upon, the parties express their wishes or wishes so that the objectives of the house sale and purchase agreement are achieved, so that when the agreement is implemented, all of these rights and obligations must be fulfilled by the parties to fulfill each other's wishes. The House Sale and Purchase Agreement when viewed from the latest legal rules, namely, the Regulation of the Minister of Public Works and Public Housing (PUPR) of the Republic of Indonesia, issued a Ministerial Regulation (Permen) PUPR Number 11 / PRT / M / 2019 concerning the Preliminary House Buying Agreement System. This regulation was signed by the Minister of PUPR, M. Basuki Hadimuljono, on July 12, 2019. This regulation regulates the sale of houses or flats by developers to the community. The issues raised in this paper are how the legal protection for home buyers is based on the Ministerial Regulation (Permen) PUPR Number 11 / PRT / M / 2019 and what are the legal requirements that home developers must have in selling their products based on Ministerial Regulation (Permen) PUPR Number 11 / PRT / M / 2019. The type of research used is juridical normative, which is research conducted based on legal materials and by collecting data, studying books in the library and the laws and regulations related to this research. The results of research by developers or housing developers that are legal entities who sell single houses, row houses and flats that are sold to the community by means of cash or credit, in terms of credit, there are many problems caused in terms of payments, broken promises, and inadequacy of development.
\end{abstract}

Keywords : PPJB, Developer, Consumer 


\section{PENDAHULUAN}

\section{A. Latar Belakang}

Tujuan dari penguasaan oleh negara atas bumi, air, dan kekayaan alam yang terkandung didalamnya adalah untuk mewujudkan sebesarbesarnya kemakmuran rakyat Indonesia. Sebagai salah satu bentuk ibadah sosial yang saling berhubungan dengan keagrariaan, maksudnya yaitu bahwa ketentuan-ketentuan hukum yang mengatur hubungan-hubungan hukum dengan bumi, air, dan ruang angkasa serta kekayaan yang terkandung didalamnya, yang dalam hal ini yaitu ialah tanah, yang mana juga tanah merupakan bagian dari Hukum Agraria.

Pentingnya profesi Notaris karena sifat dan hakikat dari pekerjaannya yang sangat berorientasi pada legalisasi atau perjanjian, yang menjadi dasar status harta benda, hak, dan kewajiban para pihak yang terlibat. Kehadiran Notaris diharapkan dapat memberikan perlindungan hukum dan kepastian hukum dalam mengakomodir kepentingan hukum para pihak yang membutuhkan jasanya. Dalam menjalankan tugas dan kewenangannya, Notaris berpedoman pada pasal 15 dan pasal 16 Undang-undang Nomor 2 tahun 2014 jo Undang-undang Nomor 30 tahun 2004 tentang Jabatan Notaris. Masyarakat membutuhkan jasa Notaris dalam membuat akta autentik terhadap perikatan yang lahir.

Dalam perkembangannya, perjanjian jual beli rumah yang dilakukan para pihak oleh Notaris menimbulkan hak dan kewajiban serta resiko bagi para pihak nantinya. Sebelum perjanjian itu disepakati, para pihak mengutarakan keinginan atau kehendaknya agar tujuan dari perjanjian jual beli rumah ini tercapai, agar ketika pelaksanaannya nanti segala hak dan kewajiban tersebut harus dipenuhi para pihak untuk saling melakukan pemenuhan masing- masing kehendak.

Perjanjian Jual Beli Rumah jika dilihat dari aturan hukum yang terbaru yaitu, Peraturan Menteri Pekerjaan Umum dan Perumahan Rakyat (PUPR) Republik Indonesia, mengeluarkan Peraturan Menteri (permen) PUPR Nomor 11/PRT/M/2019 tentang Sistem Perjanjian Pendahuluan Jual Beli Rumah. Permen ini ditandatangani Menteri PUPR, M. Basuki Hadimuljono, pada 12 Juli 2019. Permen ini, di dalamnya mengatur tentang penjualan rumah atau rumah susun oleh pengembang pada masyarakat.

Beberapa prinsip perlindungan bagi pembeli rumah diatur dalam Peraturan Menteri PUPR Nomor 11/PRT/M/2019 dalam pasal 12 ayat (1) "Calon pembeli berhak mempelajari PPJB sebelum ditandatangani paling kurang 7 (tujuh) hari kerja" dan pasal 13 ayat (1) "Dalam hal pembatalan pembelian Rumah setelah penandatanganan PPJB karena kelalaian pelaku 
pembangunan maka seluruh pembayaran yang telah diterima harus dikembalikan kepada pembeli".

Berkaitan tentang prinsip-prinsip dan lampiran perlindungan hukum terhadap pembeli rumah dari Peraturan Menteri (permen) di atas ada Undang-Undang Nomor 8 Tahun 1999 tentang Perlindungan Konsumen yang menjadi pendukung dari Peraturan Menteri di atas tertuang dalam pasal 1 Ayat (1) "Dalam Undang-undang ini yang dimaksud dengan : Perlindungan konsumen adalah segala upaya yang menjamin adanya kepastian hukum untuk memberi perlindungan kepada konsumen" dan pasal 2 "Perlindungan konsumen berasaskan manfaat, keadilan, keseimbangan, keamanan dan keselamatan konsumen, serta kepastian hukum.

Adanya kewajiban Perjanjian Pengikatan Jual Beli (PPJB) dibuat dalam akta Notaris. PPJB merupakan perjanjian pendahuluan sebelum pembelian rumah yang dinyatakan lunas dan selanjutnya dibuatkannya akta jual beli.

Perjanjian jual beli yang dibuat dalam bentuk akta serta memiliki nilai pembuktian yang sempurna, apabila ada pihak yang cidera janji, tidak dapat lagi mengelak dari kewajiban yang sudah ditentukan. Ini juga untuk penghindari PPJB yang hanya memuat klausula baku yang biasanya menguntungkan penjual, karena posisi pembeli yang tidak bebas.

Sebelum peraturan ini diterbitkan, banyak pengembang perumahan yang hanya membuatkan perjanjian pengikatan jual beli dibawah tangan, tidak dalam akta Notaris. Ketentuan didalamnya juga tidak menjamin perlindungan hak-hak pembeli.

Kententuan pasal 1338 KUHPerdata, perjanjian yang dibuat secara sah berlaku sebagai undang-undang bagi mereka yang membuatnya, tidak dapat ditarik kembali tanpa persetujuan kedua belah pihak atau karena alasan-alasan yang cukup menurut Undang-Undang yang harus dilaksanakan dengan itikad baik. ${ }^{1}$

\section{B. Rumusan Masalah}

Dari hal-hal di atas maka peneliti ingin bagaimana perlindungan hukum terhadap pembeli rumah berdasarkan Peraturan Menteri (Permen) PUPR Nomor 11/PRT/M/2019?

Diharapkan hasil penelitian ini bermanfaat terhadap pengembangan ilmu hukum dan sebagai masukan bagi para penyelenggara negara dan yang terkait.

\footnotetext{
${ }^{1}$ Abdulkadir Muhammad, 2000, Hukum Perdata Indonesia, Cet. III, Penerbit PT Citra Aditya Bakti, Bandung, hal. 233-234.
} 


\section{KERANGKA DASAR TEORI}

\section{A. Teori Negara Hukum}

Kata Tindak Pidana ditemukan dalam aturan pidana di Indonesia, antara lain ditemukan dalam Undang-Undang Nomor 19 Tahun 2002 tentang Hak Cipta, pakar lain yang menggunakan kata tindak pidana adalah Satochid Kartanegara, Menurutnya tindak pidana diartikan sebagai tindakan yang dilakukan oleh manusia untuk mana ia dapat dipidana.

a) Delik Berasal dari bahasa latin Delictum yang dapat dipakai untuk mengartikan strafbaar feit. Istilah ini dapat dijumpai dalam berbagai literatur, misalnya Utrecht meskipun beliau juga menggunakan istilah lain yaitu peristiwa pidana untuk mengartikan strafbaar feit yaitu peristiwa pidana.

b) Perbuatan Pidana Moeljatno, ia mengartikan Strafbaar feit dengan istilah perbuatan pidana, ia menuliskan bahwa perbuatan pidana merupakan suatu perbuatan yang dilarang oleh suatu aturan hukum, larangan tersebut disertai ancaman (sanksi) yang berupa pidana tertentu, bagi barang siapa melanggar aturan tersebut.

Moelijatno tidak setuju dengan penggunaan istilah tindak pidana karena menurutnya kata "tindak" lebih pendek dari "perbuatan" sehingga hanya menunjukan suatu keadaan kongkrit saja."

Setiap tindak pidana yang terdapat dalam Kitab Undang-Undang Hukum Pidana itu pada umumnya dapat dijabarkan ke dalam unsur-unsur yang pada dasarnya dapat dibagi menjadi dua macam unsur, yakni unsurunsur subjektif dan unsur-unsur objektif. Unsur-unsur subjektif itu adalah unsur-unsur yang melekat pada diri si pelaku atau yang berhubungan dengan diri si pelaku, termasuk ke dalamnya yaitu segala sesuatu yang terkandung di dalam hatinya.

Tindak pidana dikenal dengan istilah straafbar feit, akan tetapi dalam peraturan perundang-undangan Indonesia tidak ditemukan definisinya, begitupula dengan KUHP yang tidak menjelaskan secara rinci pengertian dari Straafbaar Feit tersebut. Strafbaar feit berasal dari bahasa belanda yang dibagi atas dua kata yaitu straafbaar yang berarti dapat dihukum dan feit memiliki pengertian sebagian dari suatu kenyataan, sehingga makna harfiah perkataan strafbaar feit adalah sebagian dari suatu kenyataan yang dapat dihukum, akan tetapi penjatuhan suatu hukuman tidak dapat dilakukan tanpa adanya seseorang yang melakukan perbuatan tersebut

\footnotetext{
${ }^{2}$ Leden Marpaung, 1991, Unsur- Unsur Perbuatan Yang Dapat Dihukum (Delik), Sinar Grafika, Jakarta, Hal. 3.
} 


\section{B. Teori Perjanjian}

Perjanjian adalah suatu peristiwa dimana seorang berjanji kepada orang lain atau dua orang itu saling berjanji untuk melaksanakan sesuatu hal. Hubungan antara kedua orang yang melakukan perjanjian mengakibatkan timbulnya suatu ikatan yang berupa hak dan kewajiban kedua belah pihak atas suatu prestasi. Pengertian perjanjian sebagaimana terdapat dalam Pasal 1313 Kitab Undang-Undang Hukum Perdata.

"Buku III KUH Perdata mengatur tentang Verbintenissenrecht, dimana tercakup pula istilah Overeenkomst. Dikenal dari 3 terjemahan Verbentenis, yaitu perikatan, perutangan dan perjanjian, sedangkan Overeenkomst ada 2 terjemahan, yaitu perjanjian dan persetujuan"”. Pengertian dari perjanjian itu sendiri, diatur dalam Buku III dan Bab II KUH Perdata. Pasal 1313 KUH Perdata berbunyi : Suatu perjanjian (persetujuan) adalah satu perbuatan dengan mana satu orang, atau lebih mengikatkan dirinya terhadap satu orang atau lebih.

Dapat disimpulkan bahwa di dalam perjanjian terdapat beberapa unsur yaitu :

1. Ada pihak-pihak. Pihak di sini adalah subjek perjanjian sedikitnya dua orang atau badan hukum dan harus mempunyai wewenang melakukan perbuatan hukum sesuai yang ditetapkan oleh undang-undang.

2. Ada persetujuan antara pihak-pihak, yang bersifat tetap dan bukan suatu perundingan.

3. Ada tujuan yang akan dicapai. Hal ini dimaksudkan bahwa tujuan para pihak hendaknya tidak bertentangan dengan ketertiban umum, kesusilaan dan Undang-Undang.

4. Ada prestasi yang akan dilaksanakan. Hal ini dimaksudkan bahwa prestasi merupakan kewajiban yang harus dipenuhi, oleh pihakpihak sesuai dengan syarat-syarat perjanjian.

\section{Pelaksanaan Perjanjian}

Salah satu aspek terpenting dalam perjanjian adalah pelaksanaan perjanjian. Pelaksanaan perjanjian menjadi tujuan orang-orang yang mengadakan perjanjian. "Dengan pelaksanaan perjanjian, pihak-pihak dapat memenuhi kebutuhannya, kepentingannya, serta mengembangkan bakatnya." Untuk melaksanakan suatu perjanjian, lebih dahulu harus ditetapkan secara tegas dan cermat isi perjanjian tersebut atau hak dan kewajiban masing-masing pihak. Biasanya orang mengadakan suatu perjanjian tidak mengatur atau menetapkan hal-hal yang pokok dan

\footnotetext{
${ }^{3}$ Handri Raharjo, 2009, Hukum Perjanjian di Indonesia, Penerbit Pustaka Yustitia, Yogyakarta, hal. 41.

${ }^{4}$ Ibid, hal. 229
} 
penting. Dalam jual beli misalnya, hanya ditetapkan tentang barang yang dibeli jenisnya, jumlahnya, harganya. Tidak ditetapkan tentang tempat penyerahan, biaya pengantaran, tempat dan waktu pembayaran, dan sebagainya. Perjanjian diawal bentuknya adalah PPJB (Perjanjian

Pengikatan Jual Beli), yaitu pengikatan sementara yang dilakukan antara penjual dan pembeli sebelum dilakukan Akta Jual Beli (AJB). AJB mengatur bagaimana penjual akan menjual rumahnya kepada pembeli. Isinya PPJB adalah kesepakatan penjual mengikatkan dirinya untuk menjual properti kepada pembeli disertai dengan tanda jadi atau uang muka, penjelasan tentang harga, waktu pelunasan, dan kapan dilakukan AJB. Kenapa PPJB, kenapa bukan AJB ? Karena rumahnya belum jadi dan sertifikatnya masih atas nama developer. Sertifikat tanah belum atas nama pembeli, karena statusnya masih Sertifikat tanah atas nama developer.

Pelaksanaan perjanjian pada dasarnya selalu berupa pembayaran sejumlah uang, penyerahan suatu benda, pelayanan jasa, atau gabungan dari perbuatan-perbutan tersebut. "Pembayaran sejumlah uang dan penyerahan benda dapat terjadi secara serentak dan dapat pula secara tidak serentak. Tetapi pelayanan jasa selalu dilakukan lebih dulu, baru kemudian pembayaran sejumlah uang.,

\section{Pembatalan Perjanjian}

Pembuatan perjanjian dalam prakteknya banyak sekali yang mengakhiri perjanjian atau melakukan pembatalan perjanjian, dan jika salah satu pihak tidak melaksanakan kewajibannya, maka pihak yang lain dapat membatalkan perjanjian. Sebenarnya hal ini tidak perlu di masukkan kedalam perjanjian, karena Hukum Perdata telah menerapkan prinsip umum dalam perjanjian berupa syarat batal. Pasal 1266 KUHPerdata "Syarat batal dianggap selalu dicantumkan dalam persetujuan yang timbal balik, andaikata salah satu pihak tidak memenuhi kewajibannya".

Syarat batal merupakan suatu batasan, dimana salah satu pihak tidak melaksanakan kewajibannya dalam perjanjian (wanprestasi), Apabila dalam perjanjian ternyata terdapat pelanggaran atau cacat terhadap ketentuan yang disebutkan pada pasal Perjanjian Pengikatan Jual Beli (PPJB) yang sudah disepakati oleh dua belah pihak, maka perjanjian yang telah dibuat dapat dimintakan pembatalan.

\footnotetext{
${ }^{5}$ Abdulkadir Muhammad, 2000, Hukum Perdata Indonesia, Cet. III, Penerbit PT Citra Aditya Bakti, Bandung, Hal. 236-237.
} 
Maka dalam hal ini developer atau pengembang berkewajiban untuk memenuhi syarat-syarat di atas, dan dalam hal developer tidak dapat memenuhi dari persyaratan di atas maka dan atau dalam hal ini developer memalsukan izin mendirikan bangunan (IMB) atau surat-surat penting lainnya maka pembeli berhak membatalkan Penjanjian Pengikatan Jual Beli (PPJB) dan seperti tertuang dalam Peraturan Menteri Perkerjaan Umum dan Perumahan Rakyat Nomor 11/PRT/M/2019 Tentang Sistem Perjanjian Pendahuluan Jual Beli Rumah, pasal 9 ayat (1) "Dalam hal pelaku pembangunan lalai memenuhi jadwal sebagiamana dimaksud dalam pasal 7 ayat (2) huruf a dan atau huruf $b$, calon pembeli dapat membatalkan pembelian rumah tinggal, rumah deret atau rumah susun" dan pasal 13 ayat (1) "Dalam hal pembatalan pembelian rumah setelah penandatanganan PPJB karena kelalaian pelaku pembangunan maka seluruh pembayaran yang telah diterima harus dikembalikan kepada pembeli.

\section{E. Developer atau Pengembang Perumahan}

Pengertian developer propertiadalah perusahaan yang bergerak dalam bisnis properti, dimana dia menjadi pengembang atau dapat dikatakan pembangun serta pemasaran atau marketing properti itu sendiri baik berupa perumahan skala besar maupun skala kecil. Untuk menjadi developer properti di Indonesia ada beberapa hal yang harus diketahui, saat ini pemerintah Republik Indonesia mewajibkan orang atau kelompok orang yang akan menjalankan bisnis sebagai developer properti di dalam satu wadah dengan legalitas penuh misalnya CV bahkan PT atau perseroan terbatas (lebih disarankan). "Bisnis developer properti adalah bisnis legalitas karena seluruh aktifitas developer mulai dari membeli tanah sampai dengan membangun dan pemasaran proyek bersinggungan dengan peraturan, baik berupa Undang-Undang, peraturan pemerintah, peraturan menteri dan peraturan daerah" 6 . Tentang pertanahan dan sertifikat tanah diatur dalam Undang-Undang Nomor 5 Tahun 1960 tentang UndangUndang Pokok Agraria. Selanjutnya ketika mensertifikatkan tanah diatur oleh Peraturan Pemerintah Nomor 34 Tahun 1997 tentang Pendaftaran Tanah. Selanjutnya, tentang jual beli, perjanjian dan kontrak diatur dalam Kitab Undang-Undang Hukum Perdata (KUHPer). Selain itu, tentang penjualan properti dan hubungannya dengan perbankan diatur dalam Undang-Undang Nomor 4 Tahun 1996 tentang Hak Tanggungan. Itu hanya sekelumit saja tentang aspek legalitas yang dicantumkan, selain contoh di atas masih banyak lagi peraturan-peraturan

\footnotetext{
${ }^{6} \mathrm{https}$ //asriman.com/tentang-developer-properti-yang-belum-banyak-dipahami-orang/ akses tanggal 29 Februari 2020, 12:44.
} 
yang lebih rendah yang mengatur tentang developer properti dan aktifitasnya menjual perumahan. Sebut saja Peraturan Menteri Agraria dan Tata Ruang/Kepala BPN RI (ATR/BPN), Peraturan Menteri Keuangan, Peraturan Menteri Pekerjaan Umum dan Perumahan Rakyat (PUPR). Tak ketinggalan banyak juga peraturan daerah yang mengatur langkah developer properti.

\section{F. Hak, Kewajiban, dan Tanggung Jawab Developer}

Untuk menciptakan kenyamanan dalam berusaha dan untuk menciptakan pola hubungan yang seimbang antara developer dan konsumen maka perlu adanya hak dan kewajiban masing-masing pihak. Hal tersebut lebih lanjut diatur dalam Undang-Undang Nomor 8 tahun 1999 tentang Perlindungan Konsumen. Menurut Pasal 6 Undang-Undang Nomor 8 tahun 1999 tentang Perlindungan Konsumen, meliputi:

a. Hak untuk menerima pembayaran yang sesuai dengan kesepakatan mengenai kondisi dan nilai tukar barang dan/atau jasa yang diperdagangkan.

b. Hak untuk mendapat perlindungan hukum dari tindakan konsumen yang bertikad tidak baik.

c. Hak untuk melakukan pembelaan diri sepatutnya di dalam penyelesaian hukum sengketa konsumen.

d. Hak untuk merehabilitasi nama baik apabila terbukti secara hukum bahwa kerugian konsumen tidak diakibatkan oleh barang/jasa yang diperdagangkan.

Sedangkan Pasal 7 Undang-Undang Nomor 8 Tahun 1999 tentang Perlindungan Konsumen mengatur mengenai Kewajiban developer yang meliputi:

a. Beritikad baik dalam melakukan kegiatan usahanya.

b. Memberikan informasi yang benar, jelas, dan jujur mengenai kondisi dan jaminan barang/jasa serta memberi penjelasan penggunaan, perbaikkan, dan pemeliharaan.

c. Memperlakukan atau melayani konsumen secara benar dan jujur serta tidak diskriminatif

d. Menjamin mutu barang/jasa yang diproduksi dan/atau diperdagangkan berdasarkan ketentuan standar mutu barang dan/atau jasa yang berlaku.

e. Memberi kesempatan kepada konsumen untuk menguji dan/atau mencoba barang/jasa tertentu serta member jaminan dan/atau garansi atas barang yang dibuat dan/atau yang diperdagangkan.

f. Memberi kompensasi, ganti rugi, dan/atau penggantian atas kerugian akibat penggunaan, pemakaian dan pemanfaatan barang dan/atau jasa yang diperdagangkan. 
g. Memberi kompensasi dan/atau jasa yang diterima atau dimanfaatkan tidak sesuai dengan perjanjian.

Bagi developer (pelaku usaha), selain dibebani kewajiban sebagaimana disebutkan di atas, ternyata dikenakan larangan-larangan yang diatur dalam Pasal 8 sampai dengan 17 Undang-Undang Nomor 8 tahun 1999 tentang Perlindungan Konsumen. Pasal 8 Undang-Undang Nomor 8 tahun 1999 tentang Perlindungan Konsumen mengatur larangan bagi pelaku usaha yang sifatnya umum dan secara garis besar dapat dibedakan menjadi 2 (dua), yaitu:

a. Larangan mengenai produk itu sendiri, yang tidak memenuhi syarat dan standar yang layak untuk dipergunakan atau dipakai atau dimanfaatkan oleh konsumen.

b. Larangan mengenai ketersediaan informasi yag tidak benar, tidak akurat, dan yang menyesatkan konsumen.

Di samping adanya hak dan kewajiban yang perlu diperhatikan oleh developer (pelaku usaha), ada tanggung jawab (Product Liability) yang harus dipikul oleh developer (pelaku usaha) sebagai bagian dari kewajiban yang mengikat kegiatannya dalam berusaha. Sehingga diharapkan adanya kewajiban dari developer untuk selalu bersikap hati-hati dalam memproduksi barang atau jasa yang dihasilkannya.

\section{G. Teori perlindungan hukum}

Perlindungan hukum adalah suatu perlindungan yang diberikan kepada subyek hukum yakni orang atau badan hukum ke dalam bentuk perangkat baik yang bersifat prefentif maupun yang bersifat represif, baik yang lisan maupun yang tertulis. Perlindungan hukum adalah memberikan pengayoman kepada hak asasi manusia yang dirugikan orang lain dan perlindungan tersebut diberikan kepada masyarakat agar mereka dapat menikmati semua hak-hak yang diberikan oleh hukum atau dengan kata lain perlindungan hukum adalah berbagai upaya hukum yang harus diberikan oleh aparat penegak hukum untuk memberikan rasa aman, baik secara pikiran maupun fisik dari gangguan dan berbagai ancaman dari pihak manapun.

"Perlindungan hukum adalah tindakan atau upaya untuk melindungi masyarakat dari perbuatan sewenang-wenang oleh penguasa yang tidak sesuai dengan aturan hukum, untuk mewujudkan ketertiban dan ketentraman sehingga memungkinkan manusia untuk menikmati martabatnya sebagai manusia"7.

\footnotetext{
${ }^{7}$ Setiono, 2004, Rule Of Law (supremasi hukum), Magister Ilmu Hukum Program Pascasarjana Universitas Sebelas Maret, Surakarta, Hal. 3.
} 


\section{III.METODE PENELITIAN}

Metode penelitian pada penelitian ini adalah kualitatif yaitu menjelaskan dengan kata-kata berupa narasi dengan membeberkan data yang ditemukan selama penelitian baik diperpustakaan, pengamatan dan wawancara. Lokasi penelitian di kota Samarinda, Tepatnya pada Kantor Pekerjaan Umum Kota Samrinda.

\section{IV.PEMBAHASAN}

Hukum tercipta karena adanya kumpulan manusia yang disebut masyarakat. Setiap komunitas masyarakat ada individu yang berbeda kepentingan dari setiap individu-individu lainnya, yang berusaha untuk memenuhi kepentingan pribadinya. Hukum mempunyai peranan yang sangat penting guna untuk mrngatur dari setiap masyarakat atau individu yang berada di dalam ruang lingkup hukum itu sendiri. Hukum yang bersifat memaksa dan tegas ini diharapkan bisa mengatur dan selarasnya kepentingan bersama agar tidak saling mencederai sesama manusia, kelompok atau golongan tertentu.

Developer atau pengembang perumahan yang berbadan hukum yang menjual rumah tunggal, rumah deret dan susun yang dijual kepada masyarakan dengan cara cash atau pun kredit, dalam hal kredit banyak sekali masalah yang ditimbulkan dalam hal pembayaran, ingkar janji, dan tak sesuainya pembangunan. Peraturan Menteri Pekerjaan Umum dan Perumahan Rakyat Nomor 11/PRT/M/2019 Tentang Sistem Perjanjian Pendahuluan Jual Beli Rumah hadir guna untuk memberi rasa aman bagi konsumen dan memberikan dampak yang adil bagi kedua belah pihak yang sedang dalam melakukan pengikatan jual beli rumah. Peraturan ini hadir karena banyaknya masalah yang timbul dari pengikatan ini, Negara hadir dan peraturan ini menjadi bukti bahwa negara hadir untuk melindungi rakyat, khususnya dalam hal pembeli rumah atau konsumen yang rentan untuk dimanfaatkan pihak pengembang perumahan karena posisinya yang tidak menguntungkan karena statusnya sebagai pembeli yang tidak bisa mengatur dari pihak developer atau pengembang perumahan itu sendiri. Perbandingan terbalik dengan developer atau pengembang perumahan yang mempunyai power atau tenaga untuk mengatur konsumen.

Setelah adanya hubungan hukum antara dua belah pihak, maka terdapat hak dan kewajiban yang harus dipenuhi, hak dan kewajiban sudah tertulis dalam penelitian sebelumnya, yang intinya adalah kedua belah pihak harus melaksanakan kewajiban dari apa yang telah diperjanjikan di awal dengan mengacu pada Peraturan Menteri PUPR Nomor 
11/PRT/M2019. Terjadinya perjanjian antara dua belah pihak menimbulkan hak dan kewajiban dari hal-hal tersebut dapat diperjelas dalam pasal $1338 \mathrm{KUH}$ Perdata bahwa "semua persetujuan dibuat secara sah berlaku sebagai Undang-Undang bagi mereka yang membuatnya".

Lampiran Peraturan Menteri Pekerjaan Umum dan Perumahan Rakyat Nomor 11/PRT/M/2019 Tentang Sistem Perjanjian Pendahuluan Jual Beli Rumah menyebutkan bahwa hak pembeli paling sedikit memuat:

1. Memperoleh informasi yang benar, jujur, dan akurat mengenai Rumah.

Hak atas informasi ini sangat penting karena konsumen dapat memperoleh gambaran tentang produk yang diinginkan dan dapan sesuai dangan apa dengan kebutuhan serta terhindar dari kerugian akibat dari kesalahan membeli produk. Mengenai hal ini developer atau pengembang perumahan dapat memberikan informasinya kepada konsumen atau pembeli perumahan.

2. Mengetahui syarat dan ketentuan dalam jual beli Rumah sebelum melakukan pembayaran atas harga Rumah.

Hak ini merupakan hak konsumen agar konsumen mengetahui persyaratan-peryaratan atau peraturan-peraturan yang ada atau di tetapkan oleh pengembang perumahan, agar konsumen/pembeli perumahan tidak merasa dicurangi atas peraturan atau syarat-syarat yang mengejutkan pembeli rumah.

3. Menerima serah terima Rumah pada jangka waktu sesuai dengan yang diperjanjikan.

Penerimaan serah terima surat-surat berharga yang sudah diperjanjikan juga harus memiliki kepastian dalam hal penyerah terimaan surat-surat atau pun rumah yang sudah diperjanjikan penyelesaiaan pembangunannua.

4. Mengajukan klaim perbaikan atas kondisi fisik Rumah yang tidak sesuai dengan spesifikasi yang diperjanjikan.

Jika rumah atau bangunan yang tidak sesuai dengan apa yang diperjanjikan maka konsumen atau pembeli rumah dapat mengajukan protes atau keberatan atas suatu hal yang diklaim tidak sesuai dengan apa yang diperjanjikan.

5. Mendapat perlindungan hukum dari tindakan pelaku pembangunan yang beritikad buruk.

Peraturan Menteri Pekerjaan Umum dan Perumahan Rakyat Nomor 11/PRT/M/2019 Tentang Sistem Perjanjian Pendahuluan Jual Beli Rumah, menjadi dasar serta kepastian hukum yang dihadirkan negara untuk masyarakan yang menjadi konsumen/pembeli rumah pada khususnya. 
6. Melakukan pembelaan diri sepatutnya didalam penyelesaian hukum. Setiap jual beli terkadang terdapat suatu masalah atau sengketa dari dua belah pihak yang melakukan perbuatan hukum dengan suatu sebab yang halal, maka diharapkan kedua belah pihak melakukan pembelaan diri yang sewajarnya dan sesuai porsinya masing-masing dan tidak saling menjatuhkan satu sama yang lain dengan mengutamakan asas praduga tak bersalah dengan tujuan agar permasalahan diselesaikan dengan sebaik mengkin.

7. Hak untuk membentuk perhimpunan penghuni dan pemilik Sarusun dalam pembangunan Rumah Susun sesuai dengan ketentuan peraturan perUndang-Undangan.

Ini adalah hak dari setiap konsumen/pembeli rumah untuk membuat komunitas atau grup-grup sesama pembeli rumah guna untuk mendapat informasi dari sesama pembeli rumah dengan mengutamakan tententuan Undang-Undang.

8. Hak lain yang diatur sesuai dengan ketentuan peraturan perundangperundangan dan/atau sesuai kesepakatan.

Hak-hak lainya tertuang dalam Undang-Undang Nomor 8 Tahun 1999 Tentang Perlindungan Konsumen selaras dengan peratuaran menteri pekerjaan umun dan perumahan rakyat nomor 11/PRT/M/2019.

"Hak atas keamanan dan keselamatan ini dimaksud untuk menjamin keamanan dan keselamatan konsumen dalam penggunaan barang dan/atau jasa yang diperoleh, sehingga konsumen dapat terhindar dari kerugian (fisik dan psikis) apabila mengkonsumsi suatu produk." 8

Peraturan Menteri Pekerjaan Umum dan Perumahan Rakyat Nomor 11/PRT/M/2019 Tentang Sistem Perjanjian Pendahuluan Jual Beli Rumah menjadi dasar perlindungan hukum bagi konsumen/pembeli rumah khususnya dalam pasal 5 ayat (1) "Informasi Pemasaran sebagaimana yang dimaksud dalam pasal 3 ayat (3), disampaikan pada masyarakat dengan paling sedikkit :

a. Nomor surat keterangan rencana kabupaten/kota;

b. Nomor sertifikat hak atas tanah atas nama pelaku pembangunan atau pemilik tanah yang dikerjasamakan dengan pelaku pembangunan;

c. Surat dukungan dari bank/bukan bank;

d. Nomor dan tanggal pengesahan untuk pelaku pembangunan berbadan hukum atau nomor identitas untuk pelaku pembangunan orang

${ }^{8}$ Ahmadi Miru dan Sutarman Yodo, 2014, Hukum Perlindungan Konsumen, Penerbit Rajawali Pers, Jakarta, Hal. 41 
perseorangan serta identitas pemilik tanah yang melakukan kerjasama dengan pelaku plembangunan;

e. Nomor dan tanggal penerbitan izin mendirikan bangunan induk atau izin mendirikan bangunan;

f. Rencana tapak perumahan atau rumah susun;

g. Spesifikasi bangunan dan denah rumah atau gambaran bangunan yang dipotong vertical dan memperlihatkan isi atau bagian dalam bangunan dan denah sarusun;

h. Harga jual rumah atau sarusun

i. Informasi yang jelas mengenai prasarana, sarana, dan utilitas umum yang dijanjikan oleh pelaku pembangunan; dan

j. Informasi yang jelas mengenai bagian bersama, benda bersama, dan tanah bersama untuk pembangunan rumah susun."

\section{PENUTUP}

\section{A. Kesimpulan}

Developer atau pengembang perumahan yang berbadan hukum yang menjual rumah tunggal, rumah deret dan susun yang dijual kepada masyarakan dengan cara cash atau pun kredit, dalam hal kredit banyak sekali masalah yang ditimbulkan dalam hal pembayaran, ingkar janji, dan tak sesuainya pembangunan. Peraturan Menteri Pekerjaan Umum dan Perumahan Rakyat Nomor 11/PRT/M/2019 Tentang Sistem Perjanjian Pendahuluan Jual Beli Rumah hadir guna untuk memberi rasa aman bagi konsumen dan memberikan dampak yang adil bagi kedua belah pihak yang sedang dalam melakukan pengikatan jual beli rumah. Peraturan ini hadir karena banyaknya masalah yang timbul dari pengikatan ini. Negara hadir dan peraturan ini menjadi bukti bahwa negara hadir untuk melindungi rakyat, khususnya dalam hal pembeli rumah atau konsumen yang rentan untuk dimanfaatkan pihak pengembang perumahan karena posisinya yang tidak menguntungkan karena statusnya sebagai pembeli yang tidak bisa mengatur dari pihak developer atau pengembang perumahan itu sendiri. Perbandingan terbalik dengan developer atau pengembang perumahan yang mempunyai power atau tenaga untuk mengatur konsumen. Kementerian Pekerjaan Umum dan Perumahan Rakyat (PUPR) akan melakukan sosialisasi terkait diterbitkannya Peraturan Menteri (Permen) No 11/PRT/M/2019 tentang Sistem Perjanjian Pendahuluan Jual-Beli Rumah. Hal ini terkait dengan banyaknya keberatan dari pihak developer. "Aturan itu sudah mulai jalan, kalau ada pro kontra itu pasti ada, intinya permen itu melindungi konsumen dan juga 
tidak menggannggu bisnis dari para developer". ${ }^{9}$ kata Direktorat Jendral (Dirjen) Penyediaan Perumahan Kementerian (Hamid, PUPR) Khalawi Abdul di sela acara peluncuran buku "Sejarah Perumahan" di kantor PUPR. Setiap developer perumahan harus memenuhi persyaratan untuk menjadi developer atau pengembang perumahan yang baik, dan berdasarkan Peraturan Menteri PUPR Nomor 11/PRT/M/2019 pasal 4 ayat (1) "pelaku pembangunan yang melakukan pemasaran sebagaimana dimaksud dalam pasal 3 ayat (1) dan ayat (2) harus memiliki paling sedikit :
a. Kepastian peruntukan ruang;
b. Kepastian hak atas tanah;
c. Kepastian status penguasaan tanah
d. Perizinan pembangunan perumahan atau rumah susun; dan
e. Jaminan atas pembangunan perumahan atau rumah susun dari lembaga penjamin.

\section{B. Saran-Saran}

Pelaksanaan Peraturan Menteri ini dinilai kurang melakukan sosialisasi dalam bentuk uji public terkait dengan peraturan yang ada, karena banyak dari masyarakat dikelas menengah kebawah belum mengetahui dari peraturan ini dan terjadi karena kurangnya sosialisasi kepada masyarakat menengah kebawah. Masyarakat menegah kebawah terlalu sibuk untuk bekerja dibanding membaca berita tentang beberapa hal, buktinya di tahun 2019 terjadi kasus developer nakal dan yang menjadi korbanya adalah masyarakat menengah kebawah yang hanya sibuk bekerja. Menurut penulis Peraturan Menteri Pekerjaan Umum dan Perumahan Rakyat (PUPR) Nomor 11/PRT/M/2019 Tentang Sistem Perjanjian Pendahuluan Jual Beli Rumah dirasa masih kurang mengakomodir, karena melihat dari sudut penataan ruang sesuai dengan Undang-Undang Nomor 26 Tahun 2007 Tentang Penataan Ruang, bahwasannya pasal 1 ayat 1 : Ruang adalah wadah yang meliputi ruang darat, ruang laut, dan ruang udara, termasuk ruang di dalam bumi sebagai satu kesatuan wilayah, tempat manusia dan mahluk lain hidup, melakukan kegiatan, dan memelihara kelangsungan hidupnya. Pembelian rumah dalam hal ini merupakan salah satu penunjang untuk kelangsungan hidup manusia. yang mana Undang-Undang ini sangat penting didalam peraturan ini untuk mengatur developer dalam hal penataan tata ruang pembangunan perumahan serta penjualan rumah kepada konsumen.

\footnotetext{
${ }^{9} \mathrm{https}$ //investor.id/business/pupr-akan-sosialisasikan-permen-11-tahun-2019 akses tanggal 3 April 2020, 16:15
} 


\section{DAFTAR PUSTAKA}

Abdulkadir Muhammad, 2000, Hukum Perdata Indonesia, Cet. III, Penerbit PT Citra Aditya Bakti, Bandung

Leden Marpaung, 1991, Unsur- Unsur Perbuatan Yang Dapat Dihukum (Delik), Sinar Grafika, Jakarta

Handri Raharjo, 2009, Hukum Perjanjian di Indonesia, Penerbit Pustaka Yustitia, Yogyakarta

Abdulkadir Muhammad, 2000, Hukum Perdata Indonesia, Cet. III, Penerbit PT Citra Aditya Bakti, Bandung

Setiono, 2004, Rule Of Law (supremasi hukum), Magister Ilmu Hukum Program Pascasarjana Universitas Sebelas Maret, Surakarta

Ahmadi Miru dan Sutarman Yodo, 2014, Hukum Perlindungan Konsumen, Penerbit Rajawali Pers, Jakarta 